\title{
Growth hormone response to submaximal doses of ghrelin remains unchanged during the follicular phase of the cycle
}

\author{
Christina I Messini ${ }^{1}$, Konstantinos Dafopoulos ${ }^{1}$, Maria Malandri ${ }^{1}$, Panagiotis Georgoulias ${ }^{2}$, George Anifandis $^{1}$ \\ and loannis E Messinis ${ }^{1 *}$
}

\begin{abstract}
Background: Previous data have shown that ghrelin-induced growth hormone (GH) secretion is augmented in women by exogenous but not by endogenous estrogens. The purpose of this study was to examine the response of $\mathrm{GH}$ to low-dose scheme of ghrelin administration in relation to physiological changes in estradiol levels during the normal menstrual cycle.

Methods: Ten normally cycling women were studied in two menstrual cycles. Two consecutive dosages of ghrelin $(0.15 \mathrm{\mu g} / \mathrm{kg}$ and $0.30 \mathrm{\mu g} / \mathrm{kg})$ were injected intravenously at 0 and $90 \mathrm{~min}$ in the early and late follicular phases of one cycle. Saline was injected in the preceding cycle. Blood samples were taken at -15, 0, 30, 60, 90, 120, 150 and 180 min. The GH response was assessed.

Results: Serum estradiol concentrations were significantly higher in the late than in the early follicular phase. After ghrelin, but not after saline administration, plasma ghrelin and serum GH levels increased significantly in both phases, peaking at $30 \mathrm{~min}$ and $120 \mathrm{~min}$. The peak value at $120 \mathrm{~min}$ was significantly higher than at $30 \mathrm{~min}$ $(\mathrm{P}<0.001)$. There were no significant differences in ghrelin and $\mathrm{GH}$ levels between the two phases at all time points.

Conclusions: The present results show no difference in $\mathrm{GH}$ response to two consecutive submaximal doses of ghrelin between the early and the late follicular phase of the cycle. It is suggested that estradiol is not possibly involved in the physiological process that regulates ghrelin-induced GH secretion in women during the normal menstrual cycle.
\end{abstract}

Keywords: Ghrelin, Growth hormone, Estradiol, Menstrual cycle

\section{Background}

Ghrelin is a 28 -amino acid protein, which is produced in the mucosa of the stomach but it is also expressed in other tissues. This substance is considered the endogenous ligand for the growth hormone secretagogue receptor (GHS-R) [1]. Various experiments in animals and humans have shown that ghrelin stimulates the secretion of GH together with other pituitary hormones, such as prolactin and adrenocorticotrophic hormone [2]. A role for ghrelin in the regulation of reproductive function has been suggested both in animals and in humans [3-5]. A

\footnotetext{
*Correspondence: messinis@med.uth.gr

${ }^{1}$ Department of Obstetrics and Gynaecology, School of Health Sciences,

Faculty of Medicine, University of Thessalia, Larissa, Greece

Full list of author information is available at the end of the article
}

possible site of action is the ovaries [6,7], affecting steroidogenesis in humans [8], while an inhibitory effect on LH and FSH secretion has been shown in animals, men and women [9-13].

Previous studies have shown that acylated and unacylated ghrelin and GH levels do not change significantly during the normal menstrual cycle $[14,15]$. It has been also demonstrated that the stimulating action of ghrelin on GH secretion is affected by ovarian steroids. This is based on experiments performed in postmenopausal women treated with the exogenous administration of estradiol or the combination of estradiol plus dydrogesterone [16-18]. In the two studies with estradiol alone, an enhancing effect of this steroid on ghrelin-induced GH secretion was observed with the use of either a single submaximal dose of

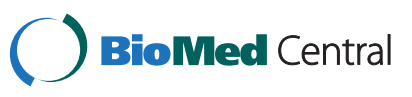


ghrelin [16] or multiple dosages in the context of a stepwise, every $90 \mathrm{~min}$, increase [17]. A more recent study, however, in normally cycling women has not shown any difference in the GH response to a single relatively high dose of ghrelin among three different phases of the cycle despite marked changes in ovarian steroids concentrations including estradiol [15]. Whether, under these conditions, low-dose schemes of ghrelin stimulation, as compared to a single high dose, could provide different GH responses, has not been investigated.

The present study was undertaken to investigate the hypothesis that the effect of two consecutive submaximal doses of ghrelin on GH secretion in the early and the late follicular phase of the menstrual cycle is not affected by changes in the physiological concentrations of estradiol in normal women.

\section{Methods}

\section{Subjects}

Ten normally cycling women (aged $22.8 \pm 3.7$ years, BMI $21.0 \pm 3.4 \mathrm{~kg} / \mathrm{m}^{2}$, mean \pm SD) were included. The length of the menstrual cycle was 27-28 days. The women volunteered for the study and gave written informed consent. Approval for the study was obtained from the local Ethical Committee. Ovulation was confirmed before the onset of the study by serum progesterone measurement and ultrasound scans of the ovaries. The women were not taking any hormonal or any other medical treatment for the last 6 months before entering the study. They had normal thyroid and adrenal function, while serum prolactin levels were within the normal range. All women were investigated during two menstrual cycles. In each cycle the same experimental procedure was performed twice, i.e. in the early follicular phase (cycle day 2) and in the late follicular phase, when the size of the dominant follicle, as assessed by ultrasound reached the diameter of 16-17 $\mathrm{mm}$. In both cycles, after overnight fasting, the women were admitted to the clinical research unit around $0930 \mathrm{~h}$. An indwelling cannula was inserted in the forearm vein and the women were left to relax for about $15 \mathrm{~min}$. Then, a blood sample was taken (time $-15 \mathrm{~min}$ ) and a second one $15 \mathrm{~min}$ later (time $0 \mathrm{~min}$ ). Immediately after the second blood sample was obtained, in the second cycle (study cycle) a single dose of $0.15 \mu \mathrm{g} / \mathrm{kg}$ ghrelin was given to the women as an acute i.v. injection. Further blood samples, in relation to time 0 , were taken at $30,60,90,120,150$ and $180 \mathrm{~min}$. A second dose of $0.30 \mu \mathrm{g} / \mathrm{kg}$ ghrelin was injected immediately after the $90 \mathrm{~min}$ blood sample. The same experimental procedure was performed twice in the first cycle preceding the study cycle with the difference that instead of ghrelin, $2 \mathrm{ml}$ of normal saline was injected i.v. at 0 and $90 \mathrm{~min}$ (control cycle). All blood samples were centrifuged at $1000 \mathrm{~g}$ for $15 \mathrm{~min}$ and serum and plasma were stored at $-20^{\circ} \mathrm{C}$ until assayed. In all blood samples, $\mathrm{GH}$ was measured. Ghrelin was measured in the samples from -15 to 120 min inclusive, while estradiol and progesterone were measured only in the 0 min sample. No side effects were seen in any of the women following the administration of ghrelin.

\section{Hormone assays}

Measurement of total ghrelin in plasma was performed using a radioimmunoassay (KIPMR90, DIASource ImmunoAssays S.A., Louvain-la-Neuve, Belgium) and the results are expressed as $\mathrm{pg} / \mathrm{ml}$. Measurement of $\mathrm{GH}$ in serum was performed using an immunoradiometric assay (hGHIRMA, IMMUNOTECH S.A.S., Marseille Cedex, France) and the results are expressed as $\mathrm{ng} / \mathrm{ml}$. Estradiol was measured in serum using a radioimmunoassay (RIAESTRADIOL, IMMUNOTECH S.A.S., Marseille Cedex, France). The results are expressed as $\mathrm{pg} / \mathrm{ml}$. Measurement of progesterone in serum was performed with the use of a radioimmunoassay (PROG-RIA-CT, DIASourse ImmunoAssays S.A., Louvain-la-Neuve, Belgium). The results are expressed as $\mathrm{ng} / \mathrm{ml}$. The lower limits of detection for ghrelin, GH, estradiol and progesterone were $40 \mathrm{pg} / \mathrm{ml}$, $0.03 \mathrm{ng} / \mathrm{ml}, 6.0 \mathrm{pg} / \mathrm{ml}$ and $0.05 \mathrm{ng} / \mathrm{ml}$ respectively. Interand intra-assay coefficients of variation were 7.1 and $4.2 \%$, 8.7 and $0.9 \%, 8.5$ and $7.5 \%$ and 6.8 and $4.2 \%$ respectively.

\section{Statistical analysis}

Hormone values were normally distributed (one sample Kolmogorov-Smirnov test) and statistical analysis was performed by repeated measures one-way analysis of variance (ANOVA) followed by Bonferroni post hoc testing and paired t-test. An $a$ level of 0.05 was used to determine statistical significance. All values are expressed as mean \pm SD. The statistical software package used was NCSS 2001 (Number Cruncher Statistical Systems, Kaysville, UT, USA).

\section{Results}

Serum estradiol concentrations on day 2 were similar in the two cycles (control cycle: $30.5 \pm 5.0 \mathrm{pg} / \mathrm{ml}$, study cycle: $26.1 \pm 4.6 \mathrm{pg} / \mathrm{ml}$ ). Follicle size (mean diameter of two measurements) and serum estradiol values (time $0 \mathrm{~min}$ ) on the day of the experiment in the late follicular phase were similar in the two cycles $(16.4 \pm 0.2$ and $16.5 \pm 0.2 \mathrm{~mm}$ and $133.1 \pm 22.6$ and $126.5 \pm 23.4 \mathrm{pg} / \mathrm{ml}$ respectively). Estradiol values in the late follicular phase were significantly higher than in the early follicular phase in both cycles $(P<0.001)$. Serum progesterone values were low in both phases of the cycle with no difference between the two cycles (mean value $<1 \mathrm{ng} / \mathrm{ml}$ ).

Figure 1 shows plasma ghrelin and serum GH levels during the two experiments. Plasma ghrelin concentrations were similar in the two cycles both in the early 


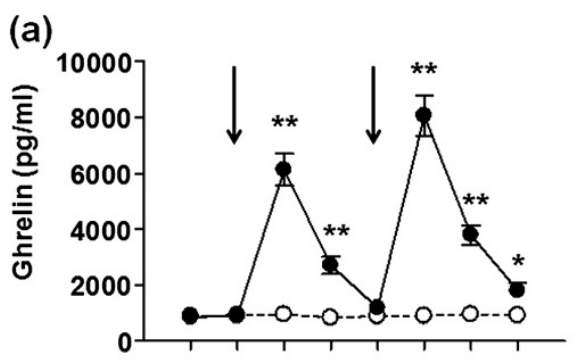

(c)

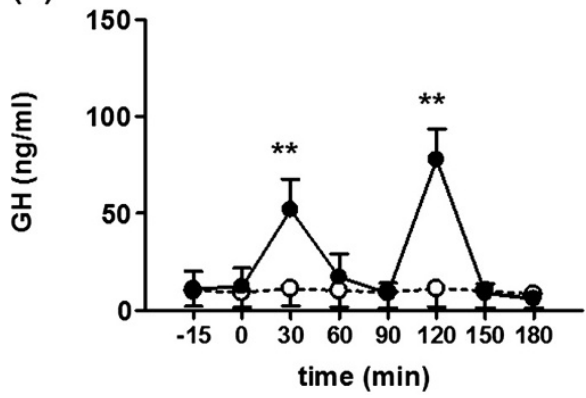

(b)

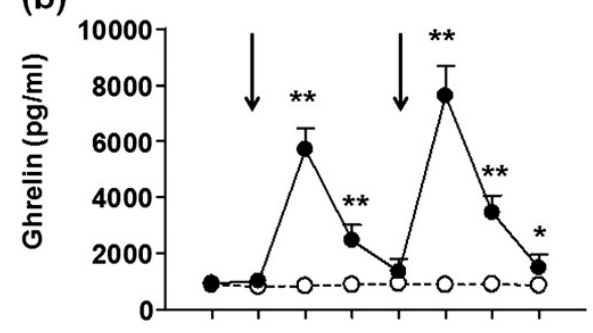

(d)

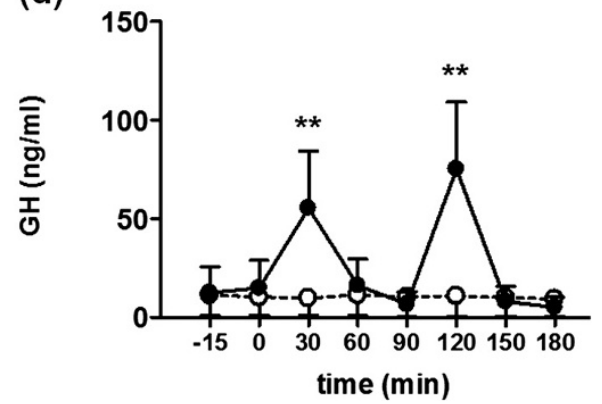

Figure 1 Plasma ghrelin and serum GH values in (a and c) early (cycle day 2) and (b and d) late follicular phase of the cycle (follicle size $16-17 \mathrm{~mm}$ ) in 10 normally cycling women before (time -15 and $0 \mathrm{~min}$ ) and after the i.v. injection (arrows) of ( $\bullet$ ) ghrelin ( $0.15 \mu \mathrm{g} / \mathrm{kg}$ at $0 \mathrm{~min}$ and $0.30 \mathbf{~} \mathrm{g} / \mathbf{k g}$ at $90 \mathrm{~min}$ ) or (o) saline $(2 \mathrm{ml}$ at 0 and $90 \mathrm{~min})$. ${ }^{* *} \mathrm{P}<0.001,{ }^{*} \mathrm{P}<0.05$ (difference from saline experiments).

(Figure 1a) and the late follicular phase (Figure 1b) before the onset of the experiment (time $0 \mathrm{~min}$ ). Ghrelin values increased significantly after each ghrelin injection. Peak values were seen at $30 \mathrm{~min}$ (early follicular: 6049 \pm 181, late follicular: $5703 \pm 362 \mathrm{pg} / \mathrm{ml}$ ) and $120 \mathrm{~min}$ (early follicular: $8010 \pm 228$, late follicular: $7613 \pm 370 \mathrm{pg} / \mathrm{ml}$ ), but the peak at 120 min was significantly higher than at $30 \mathrm{~min}$ in both phases $(\mathrm{P}<0.001)$. Plasma ghrelin values were significantly lower at $90 \mathrm{~min}$ than at $30 \mathrm{~min}$ and at 150 and $180 \mathrm{~min}$ than at $120 \mathrm{~min}$ in both phases $(\mathrm{P}<0.001)$ (Figure 1). The peak values of ghrelin at 30 and $120 \mathrm{~min}$ in the early follicular phase were similar to those in the late follicular phase respectively (Figure 2a and b). In the control cycle, plasma ghrelin values did not change significantly following the administration of saline but remained stable throughout the experimental procedure in both phases with no difference between them at all time points (Figure 1). Plasma ghrelin concentrations were significantly higher in the study cycle than in the control cycle at 30, 60, 120 and $150 \mathrm{~min}$ $(\mathrm{P}<0.001)$ as well as at $180 \mathrm{~min}(\mathrm{P}<0.05)$ in both phases (Figure 1a and b).

Serum GH values were similar before the onset of the experiment (time $0 \mathrm{~min}$ ) in the two phases of the cycle both in the control and the study cycle (Figure 1). Following the first injection of ghrelin, serum GH levels increased significantly at $30 \mathrm{~min}$ both in the early $(51.0 \pm$ $5.1 \mathrm{ng} / \mathrm{ml}, \mathrm{P}<0.001$, Figure 1c) and the late follicular phase $(55.3 \pm 4.7 \mathrm{ng} / \mathrm{ml}, \mathrm{P}<0.001$, Figure $1 \mathrm{~d})$. Then, $\mathrm{GH}$ values returned to the baseline at 60 and $90 \mathrm{~min}$ $(\mathrm{P}<0.001)$, but increased again significantly at $120 \mathrm{~min}$ following the second injection of ghrelin in the early (76.0 $\pm 5.0 \mathrm{ng} / \mathrm{ml}, \mathrm{P}<0.001$, Figure $1 \mathrm{c}$ ) and the late follicular phase $(75.2 \pm 11.3 \mathrm{ng} / \mathrm{ml}, \mathrm{P}<0.001$, Figure $1 \mathrm{~d})$. The peak value at $120 \mathrm{~min}$ was significantly higher than the peak value at $30 \mathrm{~min}$ in both phases of the cycle $(\mathrm{P}<0.001)$. A significant decrease in $\mathrm{GH}$ levels was seen at 150 and $180 \mathrm{~min}$ as compared to the $120 \mathrm{~min}$ levels in both phases of the cycle $(\mathrm{P}<0.001$, Figure $1 \mathrm{c}$ and $\mathrm{d})$. The peak values of $\mathrm{GH}$ at 30 and $120 \mathrm{~min}$ in the early follicular phase were similar to those in the late follicular phase respectively (Figure 2). In the saline experiments, serum GH values remained constant with no significant difference between the two phases at all time points. Serum GH values at 30 and $120 \mathrm{~min}$ were significantly higher in the study cycle than in the control cycle in both phases $(\mathrm{P}<0.001)$ (Figure 1c and $\mathrm{d})$. The pattern of changes in serum GH values was in both phases of the study cycle almost identical to those of plasma ghrelin values.

\section{Discussion}

The present study confirms that the exogenous administration of ghrelin stimulates in women the secretion of $\mathrm{GH}$ leading to a significant increase in serum concentrations of this hormone [2,15]. In this study, however, we used two submaximal but still pharmacological doses of ghrelin and found that the response of $\mathrm{GH}$ was dosedependent. Previous studies in postmenopausal women 
(a)

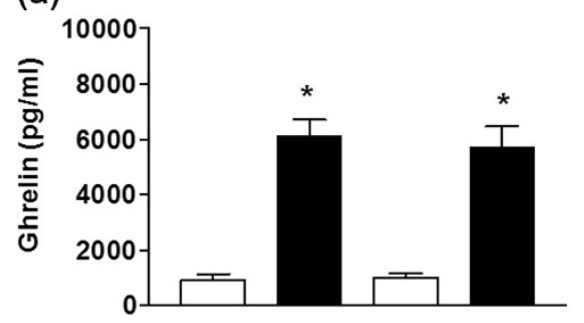

(c)

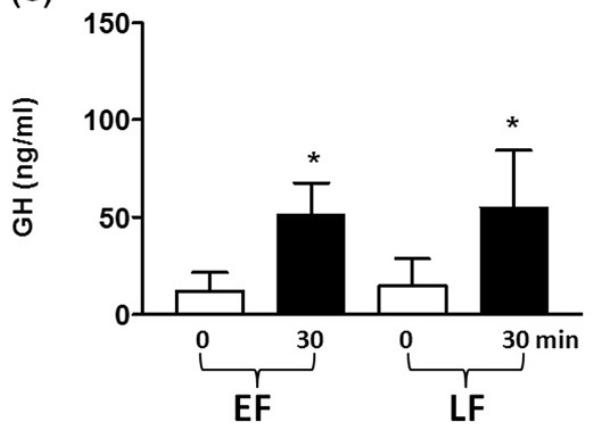

(b)

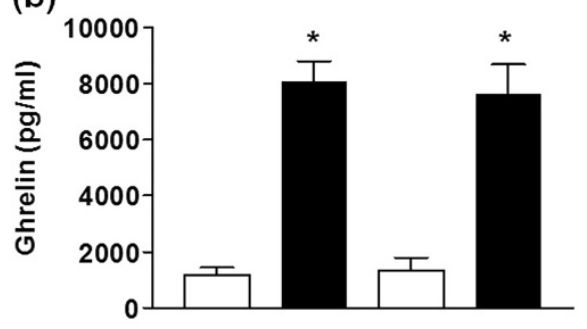

(d)

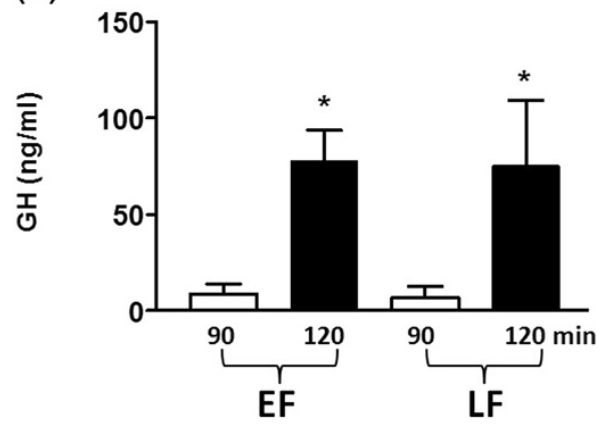

Figure 2 Plasma ghrelin and serum GH values in early (EF) and late follicular phase of the cycle (LF) in 10 normally cycling women ( $\square$ ) before (time 0 and $90 \mathrm{~min}$ ) and ( $\mathrm{a})$ after (time 30 and $120 \mathrm{~min}$ ) the i.v. injection of ghrelin at the dose of (a and c) $0.15 \mu \mathrm{g} / \mathrm{kg}$ and (b and d) $\mathbf{0 . 3 0} \mathbf{\mu g} / \mathbf{k g}$. ${ }^{* *} \mathrm{P}<0.001$ (difference between 30 and 0 min and between 120 and 90 min).

have shown that in an artificial 'simulated follicular phase', created after the exogenous administration of estrogens, the stimulating effect of a single or multiple doses of ghrelin on GH secretion was enhanced as estradiol concentrations increased [16,17]. This, however, was not confirmed in a more recent study in which the stimulating action of a single dose of ghrelin $(1 \mu \mathrm{g} / \mathrm{kg})$ on $\mathrm{GH}$ secretion was not affected by changes in the endogenous hormonal profile, such as the increasing concentrations of estradiol during the follicular phase of the cycle [15]. It was considered then, that multiple submaximal dosages of ghrelin might be more physiological than a single high dose. Nevertheless, this does not seem to be the case, since in the present study using submaximal dosages of ghrelin, we did not find any significant difference in $\mathrm{GH}$ response between the two stages of the cycle. In addition, when ghrelin was given in a previous study as a bolus at the dose of $1 \mu \mathrm{g} / \mathrm{kg}$ to a group of normal postmenopausal women treated for 60 days with the combination of $2 \mathrm{mg}$ estradiol and $10 \mathrm{mg}$ dydrogesterone, the $\mathrm{GH}$ response to that dose was also enhanced by these steroids [18]. It is suggested, therefore, that it is not the amount of ghrelin that accounts for the different results between the present and the previous studies.

It should be emphasized that the enhanced response of $\mathrm{GH}$ secretion to ghrelin in the previous studies was seen after the administration of exogenous estrogens, while in this study we took into account only endogenous estrogens. In addition to that, in the previous studies
$[16,17]$, the role of endogenous estrogens was not investigated, while the women who were included were postmenopausal. However, the model of postmenopausal women may not be the most appropriate, since due to the long-term oestrogen deprivation, the integrity of the hypothalamic-pituitary system may have been compromised. Previous data have shown a reduction in the circulating concentrations of $\mathrm{GH}$ with ageing [19], while the response of $\mathrm{GH}$ to ghrelin was attenuated in the elderly as compared to young male or female subjects [20]. It is possible, therefore, that the enhanced response of $\mathrm{GH}$ to ghrelin in postmenopausal women following the administration of oestrogens is explained on the basis of a restoration of the impaired pituitary function by these steroids, which rendered the pituitary cells more sensitive to the different secretagogues. In addition to these, previous data have shown that postmenopausal women demonstrate a reduced GH response to various secretagogues as compared to premenopausal women [21]. It has been shown previously that in experiments involving the administration of estradiol in combination with exogenous ghrelin to postmenopausal women, it was possible to predict nighttime production rates of acylated ghrelin, in the context of increased synthesis and/or acylation of ghrelin peptide by estradiol [22]. Whether endogenous estrogens could have a similar effect on ghrelin synthesis has not been investigated.

Regarding the use of GH secretagogues other than ghrelin, inconsistent results have been obtained. In the 
majority of the studies, the $\mathrm{GH}$ response to such substances was enhanced by exogenous estradiol even if the dose utilized was rather high. For instance, the response to a single dose of $3 \mu \mathrm{g} / \mathrm{kg}$ of GHRP-2 was enhanced by estradiol treatment in postmenopausal women [23]. In contrast, an enhanced response of $\mathrm{GH}$ was not seen when hexarelin was used as a stimulus at the dose of $2 \mu \mathrm{g} / \mathrm{kg}$ and the women were treated with transdermal estradiol for three months [24]. Nevertheless, in none of these studies the role of endogenous estrogens was investigated.

It is likely that the present experiments, performed in the presence of naturally increasing levels of estradiol during the follicular phase of the cycle, provide a more physiological way to investigate the role of estrogens on the endocrine actions of ghrelin rather than during a 'simulated' mode of estradiol increase. Certainly, this is a pharmacological study and not necessarily applying to the physiology. The investigation of the pulsatile secretion of acylated ghrelin in conjunction with $\mathrm{GH}$ secretion might be more appropriate, but this could be the aim of a new study with a different design. Although it might be that $\mathrm{GH}$ secretion in response to ghrelin is controlled differentially by endogenous and exogenous ovarian steroids [15], understanding the role of ghrelin on $\mathrm{GH}$ secretion during the normal menstrual cycle will certainly require a sophisticated rather than a simplified approach, as it is the use of various pharmacological tools.

\section{Conclusions}

The present results show for the first time that the response of $\mathrm{GH}$ to two consecutive submaximal doses of ghrelin was similar in the early and the late follicular phase of the cycle. Since great hormonal differences occur between these two stages, it is suggested that estradiol is not possibly involved in the physiological process that regulates ghrelin-induced $\mathrm{GH}$ secretion in women during the normal menstrual cycle.

\section{Competing interests}

The authors declare that they have no competing interests.

\section{Authors' contribution}

CIM carried out the experiments and wrote the first draft. KD participated in the experimental design and statistics. MM helped in the experiments. PG did the assays. GA participated in the analysis of the results. IEM conceived the idea and supervised the experiments. All authors read and approved the final draft.

\section{Acknowledgements}

The authors wish to thank Midwife Anastasia Tzavella for help in managing the patients.

\section{Author details}

${ }^{1}$ Department of Obstetrics and Gynaecology, School of Health Sciences, Faculty of Medicine, University of Thessalia, Larissa, Greece. ${ }^{2}$ Department of Nuclear Medicine, School of Health Sciences, Faculty of Medicine, University of Thessalia, Larissa, Greece.
Received: 11 March 2013 Accepted: 6 May 2013

Published: 10 May 2013

\section{References}

1. Kojima M, Hosoda H, Date Y, Nakazato M, Matsuo H, Kangawa K: Ghrelin is a growth-hormone-releasing acylated peptide from stomach. Nature 1999, 402:656-660.

2. Takaya K, Ariyasu H, Kanamoto N, Iwakura H, Yoshimoto A, Harada M, Mori K, Komatsu Y, Usui T, Shimatsu A, Ogawa Y, Hosoda K, Akamizu T, Kojima M, Kangawa K, Nakao K: Ghrelin strongly stimulates growth hormone release in humans. J Clin Endocrinol Metab 2000, 85:4908-4911.

3. Garcia MC, Lopez M, Alvarez CV, Casanueva F, Tena-Sempere M, Dieguez C: Role of ghrelin in reproduction. Reproduction 2007, 133:531-540.

4. Tena-Sempere M: Ghrelin as a pleotrophic modulator of gonadal function and reproduction. Nat Clin Pract Endocrinol Metab 2008, 4:666-674.

5. Angelidis G, Dafopoulos K, Messini Cl, Valotassiou V, Georgoulias P, Messinis IE: Ghrelin: new insights into female reproductive system-associated disorders and pregnancy. Reprod Sci 2012, 1:903-910.

6. Caminos JE, Tena-Sempere M, Gaytán F, Sanchez-Criado JE, Barreiro ML, Nogueiras R, Casanueva FF, Aguilar E, Diéguez C: Expression of ghrelin in the cyclic and pregnant rat ovary. Endocrinology 2003, 144:1594-1602.

7. Gaytan F, Barreiro ML, Chopin LK, Herington AC, Morales C, Pinilla L, Casanueva FF, Aguilar E, Diéguez C, Tena-Sempere M: Immunolocalization of ghrelin and its functional receptor, the type 1a growth hormone secretagogue receptor, in the cyclic human ovary. J Clin Endocrinol Metab 2003, 88:879-887.

8. Viani I, Vottero A, Tassi F, Cremonini G, Sartori C, Bernasconi S, Ferrari B, Ghizzoni L: Ghrelin inhibits steroid biosynthesis by cultured granulosalutein cells. J Clin Endocrinol Metab 2008, 93:1476-1481.

9. Furuta M, Funabashi T, Kimura F: Intracerebroventricular administration of ghrelin rapidly suppresses pulsatile luteinizing hormone secretion in ovariectomized rats. Biochem Biophys Res Commun 2001, 288:780-785.

10. Vulliémoz NR, Xiao E, Xia-Zhang L, Germond M, Rivier J, Ferin M: Decrease in luteinizing hormone pulse frequency during a five-hour peripheral ghrelin infusion in the ovariectomized rhesus monkey. J Clin Endocrinol Metab 2004, 89:5718-5723.

11. Fernandez-Fernandez R, Tena-Sempere M, Aguilar E, Pinilla L: Ghrelin effects on gonadotropin secretion in male and female rats. Neurosci Lett 2004, 362:103-107.

12. Fernández-Fernández $R$, Tena-Sempere $M$, Navarro VM, Barreiro ML, Castellano JM, Aguilar E, Pinilla L: Effects of ghrelin upon gonadotropinreleasing hormone and gonadotropin secretion in adult female rats: in vivo and in vitro studies. Neuroendocrinology 2005, 82:245-255.

13. Iqbal J, Kurose Y, Canny B, Clarke IJ: Effects of central infusion of ghrelin on food intake and plasma levels of growth hormone, luteinizing hormone, prolactin, and cortisol secretion in sheep. Endocrinology 2006, 147:510-519.

14. Dafopoulos K, Sourlas D, Kallitsaris A, Pournaras S, Messinis IE: Blood ghrelin, resistin, and adiponectin concentrations during the normal menstrual cycle. Fertil Steril 2009, 92:1389-1394.

15. Messini Cl, Dafopoulos K, Chalvatzas N, Georgoulias P, Messinis IE: Growth hormone and prolactin response to ghrelin during the normal menstrual cycle. Clin Endocrinol 2009, 71:383-387.

16. Veldhuis JD, Keenan DM, Iranmanesh A, Mielke K, Miles JM, Bowers CY: Estradiol potentiates ghrelin-stimulated pulsatile growth hormone secretion in postmenopausal women. J Clin Endocrinol Metab 2006, 91:3559-3565

17. Kok P, Paulo RC, Cosma M, Mielke KL, Miles JM, Bowers CY, Veldhuis JD: Estrogen supplementation selectively enhances hypothalamo-pituitary sensitivity to ghrelin in postmenopausal women. $J$ Clin Endocrinol Metab 2008, 93:4020-4026.

18. Villa P, Costantini B, Perri C, Suriano R, Ricciardi L, Lanzone A: Estro-progestin supplementation enhances the growth hormone secretory responsiveness to ghrelin infusion in postmenopausal women. Fertil Steril 2008, 89:398-403.

19. Chahal HS, Drake WM: The endocrine system and ageing. J Pathol 2007, 211:173-180.

20. Broglio F, Benso A, Castiglioni C, Gottero C, Prodam F, Destefanis S, Gauna C, van der Lely AJ, Deghenghi R, Bo M, Arvat E, Ghigo E: The endocrine response to ghrelin as a function of gender in humans in young and elderly subjects. J Clin Endocrinol Metab 2003, 88:1537-1542. 
21. Veldhuis JD, Cosma M, Erickson D, Paulo R, Mielke K, Farhy LS, Bowers CY: Tripartite control of growth hormone secretion in women during controlled estradiol repletion. J Clin Endocrinol Metab 2007, 92:2336-2345.

22. Paulo RC, Brundage R, Cosma M, Mielke KL, Bowers CY, Veldhuis JD: Estrogen elevates the peak overnight production rate of acylated ghrelin. J Clin Endocrinol Metab 2008, 93:4440-4447.

23. Anderson SM, Shah N, Evans WS, Patrie JT, Bowers CY, Veldhuis JD: Short-term estradiol supplementation augments growth hormone (GH) secretory responsiveness to dose-varying $\mathrm{GH}$-releasing peptide infusions in healthy postmenopausal women. J Clin Endocrinol Metab 2001, 86:551-560.

24. Arvat E, Gianotti L, Broglio F, Maccagno B, Bertagna A, Deghenghi R, Camanni F, Ghigo E: Oestrogen replacement does not restore the reduced GH-releasing activity of hexarelin, a synthetic hexapeptide, in post-menopausal women. Eur J Endocrinol 1997, 136:483-487.

doi:10.1186/1477-7827-11-36

Cite this article as: Messini et al:: Growth hormone response to

submaximal doses of ghrelin remains unchanged during the follicular phase of the cycle. Reproductive Biology and Endocrinology 2013 11:36.

\section{Submit your next manuscript to BioMed Central and take full advantage of:}

- Convenient online submission

- Thorough peer review

- No space constraints or color figure charges

- Immediate publication on acceptance

- Inclusion in PubMed, CAS, Scopus and Google Scholar

- Research which is freely available for redistribution 